\title{
An Analysis of Higher-Order Thinking Skills (HOTS) in the Learning of Economics
}

\author{
Ari Saptono1, Suparno Suparno ${ }^{2 *}$ and Agus Wibowo ${ }^{3}$ \\ Universitas Negeri Jakarta \\ Jakarta, Indonesia \\ 1https://orcid.org/0000-0002-4182-2284 \\ ${ }^{2}$ https://orcid.org/0000-0002-5518-0489 \\ 3https://orcid.org/0000-0003-0051-1743 \\ Eeng Ahman \\ Universitas Pendidikan Indonesia \\ Bandung, Indonesia \\ https://orcid.org/0000-0002-2606-5449 \\ Ismiyati Ismiyati \\ Universitas Negeri Semarang \\ Semarang, Indonesia \\ https://orcid.org/0000-0002-4706-1340 \\ Deni Sukayugi \\ Universitas Negeri Jakarta \\ Jakarta, Indonesia \\ https://orcid.org/0000-0001-7066-4361
}

\begin{abstract}
This study aims to understand the influence of self-concept, family environment, and learning environment on higher-order thinking skills (HOTS) of high school students in the Economics subject. The education landscape in the information age is rapidly changing, and all students are expected to develop their higher-order thinking skills to prepare themselves for the future. This study uses both a qualitative and quantitative approach. Eighty-seven students took part in this survey. The survey measured self-concept, family environment, and learning environment through multiple-choice questions to measure aspects of higher-order thinking skills. A multi-factor direct effect test model was used to determine the influence of each variable. Based on hypothesis testing, we found that self-concept, family environment, and learning environment have a positive influence on students' HOTS. Thus, in order to improve the higher-order thinking skills in students, it is imperative to improve self-concept, create a right family environment, and a pleasant school environment that is conducive for learning.
\end{abstract}

Keywords: higher-order thinking skills; economics; learning; selfconcept; family environment; high school competencies 


\section{Introduction}

Global competition in the 21st century is increasingly fierce, and this requires human resources to have the ability to think at a higher level. However, support for internal and external conditions is needed to improve higher-order thinking skills (HOTS) in students and learners in general (Tajudin, 2016). As the world moves into a new era of education with industry 4.0, the megatrend of education is the main issue of future learning (Kaur \& Arledge, 2019), including economics learning (Malik \& Janowska, 2018).

Indonesia is a developing country with a very high population. The young generation is the hope of the nation, and they were expected to achieve the highest level of education - developments in the 21st-century demand that young people be able to compete in an increasingly stringent global economy. The education system is faced with new challenges in how to make the appropriate changes so that students acquire modern and relevant knowledge and skills, Educational goals in the 21st century must foster problem-solving skills, critical thinking (Turiman et al., 2012; Erdoğan, 2019), and higher-order thinking skills which students need to adapt to the rapidly changing information age (DarlingHammond et al., 2020; Ball \& Garton, 2005; Greenspan et al., 2001).

The world megatrends are currently experiencing rapid development that demands corresponding changes in education, industry, and even social culture. Global megatrends are changing the environment, how we live, and the economy (Hajkowicz, Cook \& Littleboy, 2012). A megatrend is a global transformative force that determines the world of the future with its broad impact on business, society, economy, culture, and personal life (Malik \& Janowska, 2018). In this era, new technologies emerge such as artificial intelligence and mechanization that replace human work, skills and job requirements change (Aulbur \& Bigghe, 2016). Based on the phenomena, education and learning need to experience fundamentally structured changes in order to foster the true potential and curiosity that students need to continue learning according to the demands of the times (Afrianto, 2018; Hussin, 2018).

Learning is about packaging the environment for better learning (Bandura, 1971), using the right media (Moreno, 1999), shaping personality (Bandura \& Walters, 1963), fostering new entrepreneurial behavior (Collins, Witkiewitz \& Larimer, 2011). The 4th industrial revolution is a significant advancement in technology that integrates the physical, digital, and biological world, which fundamentally changes the way people work. In Industry 4.0, equipment, machinery, sensors, and people were designed to communicate with each other by using internet technology known as the 'Internet of Things.' Learning shapes students' competency and entrepreneurial skills (Suparno \& Saptono, 2018), develops character (Suparno, 2018a), and digital competencies through the use of innovative media such as ebooks and online-based resources (Suparno, 2018b).

Furthermore, industry 4.0 marks the emergence of supercomputers and Artificial Intelligence. In this condition, we can predict that robots or artificial intelligence operate many jobs. However, it is also likely that many new jobs will emerge. The 
challenge in education is how to prepare human resources can operate much artificial intelligence and not order by machines. Schools, through teachers as the frontline in education, are required to be able to improve the quality of human resources by preparing students to adapt to changes in the environment very quickly. In this case, we can make improvements to our education by changing the learning methods. Teachers must expect to take up the challenge and lead the learning process to equip students with 21st-century skills. For example, our teachers using digital technologies to create a more active, independent, creative and innovative learning process.

The progress and development of education is a factor in the success of a nation. The development of education in Indonesia is still low when viewed from the National Development Index data. Indonesia must be able to improve the quality of education, as this reflects the quality of the nation. Quality education represents the quality of graduates in an educational institution. The quality of graduates is determined by knowledge and skills that high competitiveness in the global community. To be able to compete in the global market, higher-order thinking skills are needed to support the quality of graduates (Wilson, 2000).

The purpose of economics education is to develop aspects of knowledge, understanding, attitudes, values, and skills in students. Acquiring the right skills has become an essential element in economics learning. In today's modern society, children must master thinking skills. Teachers need to teach their students to learn to think (Jhonson, 2010). Higher-order thinking skills have been widely studied (Hidayati, 2017). However, only a small amount of research specifically focuses on each subject and level of education. Through this study, students, parents, teachers, policymakers, and the general public can get some insight into the development of higher-order thinking skills in students and their current thinking abilities.

\section{Literature Review}

\section{Higher-Order Thinking Skills (HOTS)}

HOTS shows one's ability to think more broadly to find new challenges and find answers to problems (Retnawati et al., 2018; Smith \& Szymanski, 2013). The ability to think at a higher level requires someone to apply new information or prior knowledge and manipulate information to reach possible answers in new situations (Heong et al, 2011). High-level thinking is a thought process that requires students to manipulate information and ideas in certain ways that give them new understanding (Novirin, 2014). Higher-order thinking skills (HOTS) is the ability and expertise to find answers or achieve goals through various forms of thought processes. Students need to learn and practice this ability to get answers, make decisions, and solve problems (King, Goodson \& Rohani, 1998). High-level thinking is an activity that challenges students to interpret, analyze or manipulate information. Students are required to first process any new information that can produce knowledge and may provide a solution to a problem. Anderson and Krathwohl (2015) has revised the Bloom's Taxonomy to include elements of HOTS. They believe that the process of creation is the highest 
in the thinking abilities of learners. There is a strong relationship between the professional components of teachers such as educational qualifications, designation, teaching experience, research experience, training and exposure workshops with teaching strategies for higher-order thinking skills has been found that 'appointment', 'teaching experience' and 'educational qualifications' significantly contribute to the strategy of teaching higher thinking skills (Kusuma, Rosidin \& Suyatna, 2017; Dungsungnoen, 2016; Vijayaratnam, 2012; Patrick \& Ryan, 2007). The implication in this research is that the school prepares good learning facilities, the teacher conducts learning conductively, for parents to encourage, guide students at home and improve self-concept in developing thinking skills.

\section{Self-Concept}

An idea of self consists of beliefs, judgments, and views of the individual against himself is known as the concept of self. The self-concept is the overall perception a person has of himself (Slameto, 2003). Self-concept is significantly influenced by the judgment of others, peers, and one's behavior (Sampthirao, 2016). The environment greatly influences oneself to grow and develop in learning and knowledge. Therefore, the concept of self can be considered as an impression and personal view that a person has of himself and influences someone in interacting with others and the environment. The concept of self as a social product is formed through a process of internalization and organization of psychological experiences. These psychological experiences are the result of an individual's exploration of his physical environment and the reflection he receives from most people in his environment (Slameto, 2003).

\section{Family Environment}

A family is a small social group that generally consists of a father, a mother, and one or more children who have a fixed relationship and are usually based on blood ties, marriage, or adoption (Ahmadi, 2007). The family has a huge influence on the success of students. The functions carried out by the family include education, socialization, protection, bonding, religion, recreation, and affection (Adamovič, 2015). To optimize the personality and abilities of children, parents must foster an educational atmosphere within the family. The educative atmosphere starts from the womb (Suwarno, 2008). Parents have the responsibility to create a conductive pattern of life and maintain good social relations with other family members and others. The family environment is considered a foundation for each dimension of student development as well as the elements which influence student learning and thinking skills (Jackson, 2003; Wade, 2004; Campbell \& Gilmore, 2007).

\section{Learning Environment}

The school is a very important place for students to interact with their peers (Muñoz-Hurtado, 2018) and to learn from the teachers (Moore et al., 2018). Schools teach the right way of thinking and educate behavior change. The ability to think and behave in the long-term direction becomes a learning experience and habit. Student knowledge in the school environment is strongly influenced by teacher learning strategies. The school is the stage for learning (Dwiyanti, 2017). The function of the school is not much different from the function of the family 
environment. The implementation of educational learning processes in schools is intended to achieve educational goals. Learning is carried out by the teacher with strategies, models, methods, techniques, media and other evaluation tools. The learning environment in schools is an academic environment that develops knowledge, experience, and learning skills. However, thinking skills also need to be taught so that students can develop $21^{\text {st }}$ century competences by acquiring the right skills and abilities. A good infrastructure, conducive classrooms, supportive peers, innovative and open teachers with democratic learning are the demands of a good school climate. School environments that affect student learning processes will have a major impact on students' thinking abilities. A conducive school environment can be created by teachers when they are able to motivate their students to learn through good teaching strategies and rewards.

Thus, we hypothesise that self-concept, family environment, and learning environment influence the acquisition of higher-order thinking skills in students, as shown in Figure 1.

H1: There is a positive influence of self-concept towards higher-order thinking skills.

$\mathrm{H} 2$ : There is a positive influence of the family environment towards higher order thinking skills.

H3: There is influence positive learning environment towards higher-order thinking skills.

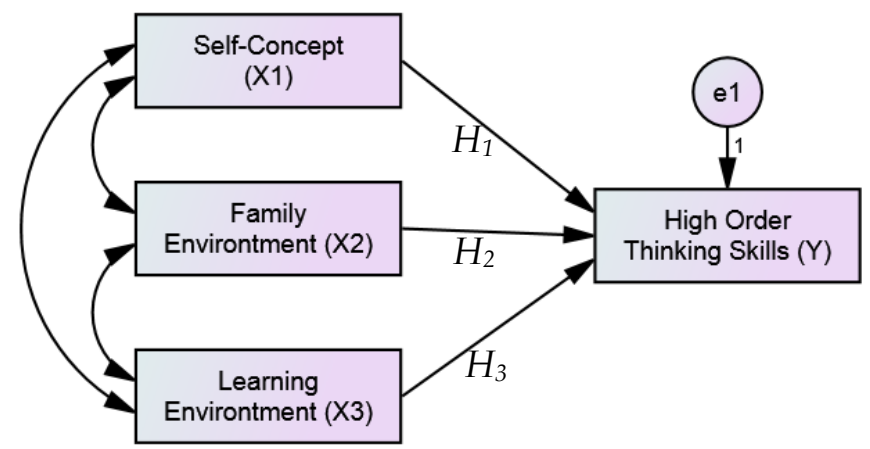

Figure 1. The Proposed Model

\section{Research Methods}

This study uses a quantitative approach with descriptive methods. Qualitative research is also used in this study because it can explore and understand the meaning of individuals or groups in developing HOTS. This study uses a multifactor analysis directly, to determine the factors forming HOTS in high school. This study uses the Single Equation Structural Model which is analyzed by multiple regression analysis, whereby the relationship between several independent variables and one dependent variable is explained. The aim is to predict the value of the dependent variable based on the known independent variable values and to explain the effect of each independent variable on the dependent variable (Tabachnick \& Fidell, 2019). According to Ho (2014), a minimum number of 20 observations for each independent variable is required to derive meaningful conclusions. 
The population in this study were Social Studies students of grade XI in a High school in Jakarta, Indonesia. There were 111 students following social studies classes but only 87 were selected to take part in the survey. The sampling technique used in this study uses a proportional random sampling technique because the characteristics of the population are homogeneous. The survey questionnaire consisted of 38 statements and 15 multiple-choice questions. The questionnaire was used to measure aspects of self-concept, family environment, and learning environment related to students' higher-order thinking skills. The multiple-choice test in this study was used to measure students' higher-order thinking skills in economics learning. The questions were on taxation in economics development and the policies of international trade. These basic competencies are usually taught in schools.

The validity of the questionnaire was testing using the Pearson test and the reliability test was tested using the Cronbach Alpha. A hypothesis prerequisite test was also performed. A value less than 0.005 using the Lilliefors test showed that the questionnaire passed the normality test. To determine the direct effect between variables, a linearity test, and correlation coefficients are calculated together with variance analysis. Data was processed and analyzed using SPSS.

\section{Results and Discussion}

In this study, we took a learning class as a teacher's assistant in the school. The questionnaire was distributed proportionally at random sampling to 3 classes of social studies with 30 questionnaires per class. We use this method according to characteristics of the population that are homogeneous with learning objectives and economics learning material. We give the respondents economics learning and Higher-Order Thinking Skills practice questions for each lesson. Furthermore, the respondents must complete one basic competency, the HigherOrder Thinking Skills formative test, for 90 minutes in class. Lastly, we give the openly questionnaire with the freedom to fill in for self-concept variables, family environment, and learning environment.

The prerequisite tests used in this study include the normality test, multicollinearity test, and the heteroskedasticity test. The next step was to perform hypothesis testing, which consists of simultaneous hypothesis testing and partial hypotheses. The F-test is performed to determine the extent to which the independent variables can explain the dependent variable. The t-test is done to determine the significance of the partial effect that each independent variable has on the dependent variable. To determine the contribution of independent variables and the dependent variable, it is also necessary to compute the coefficient of determination $\left(\mathrm{R}^{2}\right)$. The results are shown in Table 1. 
Table 1: Indicator Variables, Reliability and Percentage of Data

\begin{tabular}{|c|c|c|c|}
\hline Variable & Indicator & $\begin{array}{c}\text { Reliability } \\
\text { Test }\end{array}$ & $\begin{array}{c}\text { Data } \\
\text { Percentage }\end{array}$ \\
\hline \multirow{3}{*}{ HOTS } & Analyze & \multirow{3}{*}{0.92} & 36.9 \\
\hline & Evaluate & & 34.2 \\
\hline & Create & & 28.9 \\
\hline \multirow{4}{*}{ Self-concept } & $\begin{array}{l}\text { Self-assessment in overcoming } \\
\text { problems }\end{array}$ & \multirow{4}{*}{0.85} & 25.8 \\
\hline & Optimistic & & 23.6 \\
\hline & Assessment of roles & & 25.4 \\
\hline & Individual assessment of yourself & & 25.1 \\
\hline \multirow{8}{*}{$\begin{array}{c}\text { Family } \\
\text { environment }\end{array}$} & Parental education background & \multirow{8}{*}{0.96} & 13.2 \\
\hline & Socio-economic situation & & 12.1 \\
\hline & Education in the family & & 12.2 \\
\hline & $\begin{array}{l}\text { Involve children in giving reasons } \\
\text { for their choices and actions }\end{array}$ & & 12 \\
\hline & $\begin{array}{l}\text { Give freedom to children to express } \\
\text { their views in their way }\end{array}$ & & 12,5 \\
\hline & $\begin{array}{l}\text { Loosen controls that reduce a child's } \\
\text { self-confidence }\end{array}$ & & 13.5 \\
\hline & Inspire perseverance & & 12.6 \\
\hline & Provide creative atmosphere & & 12.3 \\
\hline \multirow{3}{*}{$\begin{array}{c}\text { Learning } \\
\text { environment }\end{array}$} & $\begin{array}{l}\text { Learning Process that supports } \\
\text { HOTS }\end{array}$ & \multirow{3}{*}{0.88} & 34.1 \\
\hline & $\begin{array}{l}\text { Provide Intrinsic Motivation to } \\
\text { students }\end{array}$ & & 34.4 \\
\hline & $\begin{array}{l}\text { Giving awards to HOTS learning } \\
\text { process }\end{array}$ & & 31.6 \\
\hline
\end{tabular}

To improve students' higher-order thinking skills, students should start by loving themselves and developing positive thoughts that will encourage them to stay optimistic, brave, and to never give up in the face of risks and challenges. Our way of thinking controls our attitudes, actions, and lives. Encouragement from parents can provide motivation and encourage children's interest in thinking. Parents also need to pay more attention to the learning facilities that their children have at home. They also need to develop a positive attitude to improve the higherorder thinking skills of their children. 
Table 2: Multiple Regression Test Results

\begin{tabular}{|c|c|}
\hline Statistics & $Y=$ Higher-Order Thinking Skills \\
\hline$C$ & 0.914 \\
\hline$X_{1}$ & 0.784 \\
\hline$X_{2}$ & 0.323 \\
\hline$X_{3}$ & 0.655 \\
\hline \multirow{2}{*}{$t\left(X_{1}\right)$} & $0.005^{*}$ \\
\cline { 2 - 3 } & $(2.872)^{* *}$ \\
\hline \multirow{2}{*}{$t\left(X_{2}\right)$} & $0.023^{*}$ \\
\cline { 2 - 3 } & $(2.319)^{* *}$ \\
\hline \multirow{2}{*}{$t\left(X_{3}\right)$} & $0.019^{*}$ \\
\cline { 2 - 3 } & $(2.394))^{* *}$ \\
\hline$F$ & $28.279^{* * *}$ \\
\hline$R>$ & 0.505 \\
\hline
\end{tabular}

*** $2.71, * *>1.96 *>0.05$, C: Constants

$\mathrm{X}_{1}$ : Self-concept, $\mathrm{X}_{2}$ : Family environment, $\mathrm{X}_{3}$ : Learning environment

Based on the test results, it is evident that self-concept, family environment, and learning environment significantly influence the ability to think at a higher level. This means that all hypotheses put forward in this study can be accepted. H1, H2, and $\mathrm{H} 3$ are significant with a count of 2.872, 2.319, and 2.394, respectively, as shown in Table 2. Table 2 also shows that the multiple linear regression equation is $\mathrm{Y}=0.914+0.784 \mathrm{X}_{1}+0.323 \mathrm{X}_{2}+0.655 \mathrm{X}_{3}$. The coefficient value of self-concept $(\mathrm{X} 1)$ is 0.784 and is positive. The significance value (0.05) for the self-concept variable $\left(X_{1}\right)$ shows that students are able to think at a high level. The t-value of the selfconcept variable is 2.872 . The $t$-table value that has been sought and determined is 1.96. The equation to find the value of two-way test $t$-table is $t$-table $=(\alpha / 2$; df), with a $95 \%$ confidence level, with the value of $\alpha=5 \%$ or 0.05 . $d f=$ degree of freedom is determined by the formula: $n-k$, where $n=$ number of samples and $\mathrm{k}$ $=$ number of variables (independent $\&$ dependent). There are 87 samples and 4 research variables. So we can conclude that the value of $\mathrm{df}$ is $87-4=83$. Based on the distribution of the value of $\mathrm{t}$-Table, a value of 1,992 is obtained. This shows that the compensation variable is greater than the $t$-table value $(2.872 \geq 1.96)$. So, it can be concluded that $\mathrm{H} 1$ is accepted. The concept of self becomes the foundation for someone who will later form a self-image. The introduction, understanding and evaluation of oneself is a very influential capital for students to achieve their expected learning achievements (Effendi, 2004). People with high self-concept can set higher aspirations than people with low self-concept. They 
may be more willing to survive in the face of initial failures and tend to do more effort to paralyze feelings of incompetence and self-doubt.

The significance value (0.023) for the family environment variable $\left(X_{2}\right)$ shows that students are able to think at a high level. The $t$-value of the family environment variable is 2.319. This shows that the compensation variable is greater than the $\mathrm{t}$ table value $(2,319 \geq 1.96)$. So it can be concluded that $\mathrm{H} 2$ is accepted. The family environment is related to high-order thinking skills. Children's creativity needs to be encouraged by the family, and the parents need to be wiser in control otherwise it will reduce the children's confidence in dealing with problems (Keshta \& Seif, 2013). The condition of the family environment will encourage children's interest in thinking critically, thus developing the relevant higher order thinking skills. Family characteristic also influences HOTS indirectly through psychology (Sungu, 2015).

The significance value (0.019) for the learning environment variable $\left(\mathrm{X}_{3}\right)$ shows that the students are able to think at a high level. The $t$-value of the learning environment variable is 2.394 . This shows that the compensation variable is greater than the t-table $(2.394 \geq 1.96)$. So, it can be concluded that $\mathrm{H} 3$ is accepted. The R-value of 0.771 indicates that the influence of self-concept, family environment, and learning environment on students' higher-order thinking skills is strong. The determinant coefficient $\left(\mathrm{R}^{2}=0.505\right)$ shows that about $50.5 \%$ of higher-order thinking skills are influenced by the concept of self, family environment and learning environment, and about $49.5 \%$ are influenced by other variables that are not described in this study.

Table 3: Mean Scores of Students' HOTS data

\begin{tabular}{|c|c|c|c|c|c|c|}
\hline No & Indicator & Item & Score & Total Score & Mean & Percentage \\
\hline 1 & Analyze & $\begin{array}{c}1 \\
2 \\
5 \\
9 \\
10\end{array}$ & $\begin{array}{l}69 \\
63 \\
79 \\
75 \\
55\end{array}$ & 341 & 68.2 & $36.9 \%$ \\
\hline 2 & Evaluate & $\begin{array}{c}3 \\
4 \\
8 \\
11 \\
12 \\
\end{array}$ & $\begin{array}{l}81 \\
73 \\
59 \\
33 \\
70 \\
\end{array}$ & 316 & 63.2 & $34.2 \%$ \\
\hline 3 & Create & $\begin{array}{c}6 \\
7 \\
13 \\
14 \\
15\end{array}$ & $\begin{array}{l}38 \\
56 \\
74 \\
73 \\
26\end{array}$ & 267 & 53.4 & $28.9 \%$ \\
\hline
\end{tabular}

Table 3 shows the total scores for the 15 MCQs on Economics which were attempted by 90 students. The best score of 81 was obtained for question 3 which was about the reporting of incoming tax payments. This shows that question 81 was the easier question and that perhaps students find this topic very interesting 
to learn. Students also scored very well on questions 1, 4, 5, 9, 12, 13 and 14 . The lowest score of 26 was obtained for question 15 which was about exports, imports and trade balance. This shows that question 15 was by far the most difficult question and that most students have difficulties with understanding the trade balance concept. Students also had much difficulties with questions 6 and 11 where the scores were less than the mean. The overall mean score for the class was 61.6. The mean score for analysis skills was highest while the mean score for creativity skills was lowest. However, the ability of students in HOTS for Economics is still below the national minimum required level of 75 .

Table 4: Mean Scores of Self-concept data

\begin{tabular}{|c|c|c|c|c|c|c|}
\hline No & Indicator & Item & Score & Total Score & Mean & Percentage \\
\hline 1 & $\begin{array}{l}\text { Self-assessment } \\
\text { in overcoming } \\
\text { problems }\end{array}$ & $\begin{array}{l}1 \\
2\end{array}$ & $\begin{array}{l}321 \\
312\end{array}$ & 633 & 316.5 & $25.82 \%$ \\
\hline 2 & Optimism & $\begin{array}{l}3 \\
4 \\
5\end{array}$ & $\begin{array}{l}298 \\
275 \\
297\end{array}$ & 870 & 290 & $23.67 \%$ \\
\hline 3 & $\begin{array}{l}\text { Assessment of } \\
\text { roles }\end{array}$ & $\begin{array}{l}6 \\
7\end{array}$ & $\begin{array}{l}300 \\
323\end{array}$ & 623 & 311.5 & $25.41 \%$ \\
\hline 4 & $\begin{array}{l}\text { Individual } \\
\text { assessment of } \\
\text { yourself }\end{array}$ & $\begin{array}{c}8 \\
9 \\
10\end{array}$ & $\begin{array}{l}318 \\
289 \\
316\end{array}$ & 923 & 307.7 & $25.10 \%$ \\
\hline
\end{tabular}

On a maximum scale of 450 points, the overall mean score for the self-concept variable was 304.9. The differences between the four indicators are not significant although from Table 4, we can see that the mean score for 'Optimism' was the lowest. Thus, necessary actions must be undertaken at the school level to increase the degree of optimism in their students. This includes the confidence in the ability to do a task, solving economics problems and increasing their ability to understand the materials taught.

Table 5: Mean Scores of Family Environment data

\begin{tabular}{|c|c|c|c|c|c|c|}
\hline No & Indicator & Item & Score & Total Score & Mean & Percentage \\
\hline 1 & $\begin{array}{l}\text { Parental education } \\
\text { background }\end{array}$ & $\begin{array}{l}1 \\
2\end{array}$ & $\begin{array}{l}348 \\
322\end{array}$ & 670 & 335 & $13.20 \%$ \\
\hline 2 & $\begin{array}{l}\text { Socio-economic } \\
\text { situation }\end{array}$ & $\begin{array}{l}3 \\
4\end{array}$ & $\begin{array}{l}307 \\
305\end{array}$ & 612 & 306 & $12.06 \%$ \\
\hline 3 & $\begin{array}{l}\text { Education in the } \\
\text { family }\end{array}$ & $\begin{array}{l}5 \\
6 \\
7 \\
8\end{array}$ & $\begin{array}{l}315 \\
340 \\
297 \\
283\end{array}$ & 1235 & 308.8 & $12.17 \%$ \\
\hline 4 & $\begin{array}{l}\text { Involve children in } \\
\text { giving reasons for } \\
\text { their choices and } \\
\text { actions }\end{array}$ & $\begin{array}{c}9 \\
10\end{array}$ & $\begin{array}{l}300 \\
310\end{array}$ & 610 & 305 & $12.03 \%$ \\
\hline
\end{tabular}




\begin{tabular}{|c|l|c|c|c|c|c|}
\hline 5 & $\begin{array}{l}\text { Give freedom to } \\
\text { children to express } \\
\text { their views in their } \\
\text { way }\end{array}$ & $\begin{array}{l}11 \\
12\end{array}$ & $\begin{array}{l}334 \\
299\end{array}$ & 633 & 316.5 & $12.47 \%$ \\
\hline 6 & $\begin{array}{l}\text { Loosen controls } \\
\text { that reduce a } \\
\text { child's self- } \\
\text { confidence }\end{array}$ & $\begin{array}{l}13 \\
14\end{array}$ & $\begin{array}{l}338 \\
333\end{array}$ & 671 & 335.5 & $13.22 \%$ \\
\hline 7 & $\begin{array}{l}\text { Inspire } \\
\text { perseverance }\end{array}$ & 15 & $\begin{array}{l}297 \\
16\end{array}$ & 636 & 318 & $12.53 \%$ \\
\hline 8 & $\begin{array}{l}\text { Provide a creative } \\
\text { atmosphere }\end{array}$ & $\begin{array}{l}17 \\
18\end{array}$ & $\begin{array}{l}299 \\
326\end{array}$ & 625 & 312.5 & $12.32 \%$ \\
\hline
\end{tabular}

On a maximum scale of 450 points, the overall mean score for the family environment variable was 316.2. However, differences between the eight indicators are not significant. Nevertheless, the mean scores were highest for indicators 1 and 6 and they were lowest for indicators 2 and 4 . Families need to involve children's opinions in family activities, example by asking children to give reasons for their choices and actions. This will favour the development of a conducive family environment, as it will stimulate student's growth in HOTS. It is also essential to involve children in decision-making in the family in order to develop their freedom to think critically during their teenage years.

Table 6: Mean Scores of Learning Environment data

\begin{tabular}{|c|c|c|c|c|c|c|}
\hline No & Indicator & Item & Score & Total Score & Mean & Percentage \\
\hline 1 & $\begin{array}{l}\text { Learning } \\
\text { process that } \\
\text { supports HOTS }\end{array}$ & $\begin{array}{l}29 \\
30 \\
31 \\
32 \\
33 \\
34\end{array}$ & $\begin{array}{l}289 \\
278 \\
276 \\
303 \\
307 \\
271\end{array}$ & 1724 & 287.3 & $34.05 \%$ \\
\hline 2 & $\begin{array}{l}\text { Provide intrinsic } \\
\text { motivation to } \\
\text { students }\end{array}$ & $\begin{array}{l}33 \\
36\end{array}$ & $\begin{array}{l}287 \\
293\end{array}$ & 580 & 290 & $34.37 \%$ \\
\hline 3 & $\begin{array}{l}\text { Giving awards } \\
\text { to HOTS } \\
\text { learning process }\end{array}$ & $\begin{array}{l}37 \\
38\end{array}$ & $\begin{array}{l}283 \\
250\end{array}$ & 533 & 266.5 & $31.58 \%$ \\
\hline
\end{tabular}

On a maximum scale of 450 points, the overall mean score for the learning environment variable was 283.7. The mean scores for indicators 1 and 2 were above the global average while it was less for indicator 3 . Thus, providing an adequate infrastructure and learning facilities give students comfort in their learning activities. Feedback from teachers is an essential component of the learning process. Feedback is deemed to be even more helpful for students with weaker academic abilities. The need to appreciate the work of teachers and that of students in an essential ingredient that must be encouraged in order to make the inclusion of HOTS activities a success in the school environment. 
The highest score was achieved in family environment (70.3\%), followed closely by self-concept $(67.8 \%)$, while learning environment had the lowest score, which was much less than $300(63.0 \%)$ on a scale of 450 . These results show that, in general, most children believe that they a good family environment, irrespective of their socio-economic status. Most students also valued themselves well. The school learning environment required the most improvement. The lack of appropriate learning facilities was the main reason for this poor score. It is believed that the above three factors can contributed to the enhancement of HOTS skills in students. The mean score, in terms of percentages, in the MCQ Economics test was $68.4 \%$ while the overall mean score for the three variables combined is $67.7 \%$. Thus, there is a very high correlation between these two values. Nevertheless, further studies are required to confirm any possible causal effects.

\section{Conclusion \& Recommendations}

This study aims to understand the influence of self-concept, family environment, and learning environment on higher-order thinking skills (HOTS) of high school students in the Economics subject. The education landscape in the information age is rapidly changing, and all students expect to develop their higher-order thinking skills in order to prepare themselves for the future of learning. Based on the results of this study, we can conclude that self-concept, family environment, and learning environment influence students' higher-order thinking skills in the learning of Economics. Based on regression coefficients, we can also say that selfconcept has the highest influence but closely followed by the learning environment. The family environment had the least influence on HOTS and the learning of issues related to Economics. We can also conclude that schools must provide intrinsic motivation to students and must also value the teaching and learning of thinking skills. This can be achieved by rewarding teachers and students appropriately. Schools must create ecosystems that nurture, support, and respect thinking skills. Schools must also provide training programs for teachers on how to teach thinking skills so that they can apply it in the learning process in their classrooms. Further studies still need to be carried out to find the other factors which affect higher-order thinking skills. This study can also be replicated in other schools and other regions and with a larger sample so that comparisons can be made.

\section{References}

Adamovič, M. (2015). The Impact of Family and School Cooperation on the Quality of the Education Process for Formation of Personality and Performance of Students. Open Online Journal for Research and Education, 4(12), 1-5.

Afrianto. (2018). Being a Professional Teacher in the Era of Industrial Revolution 4.0: Opportunities, Challenges and Strategies for Innovative Classroom Practices Afrianto Faculty of Teachers Training and Education (FKIP), Universita. English Language Teaching and Research, 2(1), 1-13. Retrieved from http://ejournal.unp.ac.id/index.php/eltar/article/view/102675/101032

Ahmadi, A. (2007). Educational Sociology. Jakarta, Indonesia: Rineka Cipta.

Anderson, L . W., \& Krathwohl, D. R. (2015). Learning Framework, Teaching, and Assessment. Yogyakarta, Indonesia: Pustaka Pelajar. 
Aulbur, W., Arvind, C. J., \& Bigghe, R. (2016). "BRICS skill development for Industry 4.0". Roland Berger, BRICS Skill Development Working Group, Indian Section, 1-50. Retrieved from http://www.globalskillsummit.com/Whitepaper-Summary.pdf

Ball, A. L., \& Garton, B. L. (2005). Modeling Higher Order Thinking: The Alignment Between Objectives, Classroom Discourse, And Assessments. Journal of Agricultural Education, 46(2), 58-69. https://doi.org/10.5032/jae.2005.02058

Bandura, A. (1971). Social Learning Theory. New York: General Learning Press.

Bandura, A., \& Walters, R. H. (1963). Social learning and personality development. New York: Holt, Rinehart \& Winston.

Campbell, J., \& Gilmore, L. (2007). Intergenerational continuities and discontinuities in parenting styles. Australian Journal of Psychology, 59(3), 140-150. https://doi.org/10.1080/00049530701449471

Collins, S. E., Witkiewitz, K., \& Larimer, M. E. (2011). The theory of planned behavior as a predictor of growth in risky college drinking. Journal of Studies on Alcohol and Drugs, 72(2), 322-332. https:// doi.org/10.15288/jsad.2011.72.322

Darling-Hammond, L., Flook, L., Cook-Harvey, C., Barron, B., \& Osher, D. (2019). Implications for educational practice of the science of learning and development. Applied Developmental Science, 24(2), 97-140. https://doi.org/10.1080/10888691.2018.1537791

Dungsungnoen, A. P., \& Shukla, D. (2016). Student's Perceived Level and Teachers' Teaching Strategies of Higher Order Thinking Skills; A Study on Higher Educational Institutions in Thailand. Journal of Education and Practice, 7(12), 211219.

Dwiyanti, W. (2017). The Stage ' s of Sharing Knowledge among Students in Learning Environment: A Review of Literatur. International Journal of Education and Research, 5(8), 81-92.

Effendi, K. (2004). Relationship between Self Concept and Verbal Ability and Learning Achievement in Fifth Grade Students of Muhammadiyah Sukonandi Yogyakarta Elementary School. Humanitas, 1(1), 26-31.

Erdoğan, V. (2019). Integrating 4C Skills of 21st Century into 4 Language Skills in EFL Classes Vacide Erdoğan. International Journal of Education and Research, 7(11), 113124. Retrieved from https://www.ijern.com/journal/2019/November2019/09.pdf

Greenspan, A. (2001). Remarks by Chairman Alan Greenspan: The importance of education in today's economy. Speech presented at the Community Affairs Research Conference of the Federal Reserve System, April 6. Retrieved from https://www.bis.org/review/r010409b.pdf

Hajkowicz, S., Cook, H., \& Littleboy, A. (2012). Our future world: Global megatrends that will change the way we live. Brisbane, Australia: Commonwealth Scientific and Industrial Research Organisation. https://doi.org/10.4225/08/584ee9706689b

Heong, Y. M., Othman, W. D., Md Yunos, J., Kiong, T. T., Hassan, R., \& Mohamad, M. M. (2011). The Level of Marzano Higher Order Thinking Skills Among Technical Education Students. International Journal of Social and Humanity, 1(2), 121-125. https://doi.org/10.7763/IJSSH.2011.V1.20

Hidayati, A. U. (2017). Practicing Higher Level Thinking Skills in Learning Mathematics in Elementary School Students. Journal of Skilled, 4(2), 143-156. https:// doi.org/10.24042/terampil.v4i2.2222

Ho, R. (2013)). Handbook of univariate and multivariate data analysis with IBM SPSS (Second edition). New York: Chapman and Hall/CRC.

Hussin, A. A. (2018). Education 4. 0 Made Simple: Ideas For Teaching. International Journal of Education and Literacy Studies, 6(3), 92-98. 
Jackson, A. P. (2003). The effects of family and neighborhood characteristics on the behavioral and cognitive development of poor black children: A longitudinal study. American Journal of Community Psychology, 32, 175-186.

Jhonson, E. B. (2010). Contextual Teaching and Learning: Makes Teaching and Learning Activities Fun and meaningful. Bandung, Indonesia: Kaifa.

Kaur, N., \& Arledge, J. (2019). One Day National Seminar " Digitalization of Higher Education " Digitization of education in the 21st century. International Journal of Applied Research, SP4, 20-22. Retrieved from http://www.allresearchjournal.com/archives/2019/vol5issue4S/PartI/SP-5-485-420.pdf

Keshta, A. S., \& Seif, A. (2013). Evaluating the Higher Order Thinking Skills in Reading of English for Palestine Grade Eight. Asian Journal of Education and E-Learning, 1(1), 2321-2454. Retrieved

from http:/ /library.iugaza.edu.ps/thesis/105688.pdf\%0Awww.ajouronline.com

King, F. J., Goodson, L., \& Rohani, F. (1998). Higher order thinking skills, Center for Advancement of Learning and Assessment, Florida State University. Retrieved from http://www.cala.fsu.edu/files/higher_order_thinking_skills.pdf.

Kusuma, M. D., Rosidin, U., \& Suyatna, A. (2017). The Development of Higher Order Thinking Skill ( Hots ) Instrument Assessment In Physics Study. IOSR Journal of Research \& Method in Education, 7(1), 26-32. https://doi.org/10.9790/73880701052632

Malik, R., \& Janowska, A. (2018). Megatrends and their use in economic analyses of contemporary challenge in the world economy. Prace Naukowe Uniwersytetu Ekonomicznego we Wroclawiu, 210-221. https://doi.org/10.15611/pn.2018.523.18

Moore, G. F., Cox, R., Evans, R. E., Hallingberg, B., Hawkins, J., \& Littlecott, H. J. (2018). School, Peer and Family Relationships and Adolescent Substance Use, Subjective Wellbeing, and Mental Health Symptoms in Wales : a Cross-Sectional Study. Child Indicators Research, 11(6), 51-65.

Moreno, R., \& Mayer, R. E. (1999). Cognitive principles of multimedia learning: The role of modality and contiguity. Journal of Educational Psychology, 91(2), 358-368. https://doi.org/10.1037/0022-0663.91.2.358

Muñoz-Hurtado, J. (2018). The role of teachers on students' peer groups relations : a review on their influence on school engagement and academic achievement. Revista Interdisciplinaria de Filosofía y Psicología, 13(42), 30-43. Retrieved from https://scielo.conicyt.cl/pdf/limite/v13n42/0718-1361-limite-13-42-30.pdf

Novirin, D. (2014). The effectiveness of the application of the method of group investigation in improving the ability to think at a high level and the learning achievement of students in class $X$ in Entrepreneurship (Thesis). Retrieved from http:/ /eprints.uny.ac.id/16013/1/Skripsi\%20David\%20Novirin.pdf.

Patrick, H., Ryan, A. M., \& Kaplan, A. (2007). Early adolescents' perceptions of the classroom social environment, motivational beliefs, and engagement. Journal of Educational Psychology, 99(1), 83-98. https://doi.org/10.1037/0022-0663.99.1.83

Retnawati, H., Djidu, H., Kartianom, Apino, E., \& Anazifa, R. D. (2018). Teachers' knowledge about higher-order thinking skills and learning strategy. Problems of Education in the 21st Century, 76(2), 215-230. Retrieved from http:/ / oaji.net/articles/2017/457-1524597598.pdf

Sampthirao, P. (2016). Self-concept and interpersonal communication. The International Journal of Indian Psychology, 3(3), 177-189 https:/ / doi.org/10.25215/0303.115

Slameto. (2003). Learning and Factors That Influence It. Jakarta, Indonesia: Rineka Cipta. 
Smith, V. G., \& Szymanski, A. (2013). Critical Thinking: More Than Test Scores. NCPEA International Journal of Educational Leadership Preparation, 8(2), 16-26.

Sukardi. (2009). Educational Research Methodology: Competencies and Practices. Jakarta, Indonesia: PT Bumi Aksara.

Sungu, H. (2015). Attitudes towards substance addiction: A study of Turkish University students. Educational Research and Reviews, 10(7), 10151022. https://doi.org/10.5897/ERR2015

Suparno, S. (2018). Analysis of Smart Character Forming Factors of Students in Integrated Islamic Schools. Jurnal Pendidikan Karakter, 1(8), 62-73. https://doi.org/10.21831/jpk.v8i1.21675

Suparno, S. (2018). Development of E-Book Multimedia Model to Increase Critical Thinking of Senior High School Students. Dinamika Pendidikan, 12(2), 196-206. https://doi.org/10.15294/dp.v12i2.13567

Suparno, S., \& Saptono, A. (2018). Entrepreneurship education and its influence on financial literacy and entrepreneurship skills in college. Journal of Entrepreneurship Education, 21(4), 1-11.

Suwarno W. (2008). Fundamentals of Educational Sciences. Yogyakarta, Indonesia: Ar-Ruzz Media

Tabachnick, B. G., \& Fidell, L. S. (2019). Using Multivariate Statistics. Boston, MA: Pearson. Retrieved from https://www.pearsonhighered.com/assets/preface/0/1/3/4/0134790545.pdf.

Tajudin, N. M., \& Chinnappan, M. (2016). The Link Between Higher Order Thinking Skills, Representation and Concepts in Enhancing TIMSS Tasks. International Journal of Instruction, 9(2), 199-214. https:/ / doi.org/10.12973/iji.2016.9214a

Third, A., Bellerose, D., Oliveira, J. D. D., Lala, G., \& Theakstone, G. (2017). Young and Online: Children's perspectives on life in the digital age. Sydney, Australia: Western Sydney University.

Turiman, P., Omar, J., Daud, A. M., \& Osman, K. (2011). Fostering the 21st Century Skills through Scientific Literacy and Science Process Skills. Procedia - Social and Behavioral Sciences, 59, 110-116. https://doi.org/10.1016/j.sbspro.2012.09.253

Vijayaratnam, P. (2012). Developing Higher Order Thinking Skills and Team Commitment via Group Problem Solving: A Bridge to the Real World. Procedia - Social and Behavioral Sciences, 66, 53-63. http:// doi.org/10.1016/j.sbspro.2012.11.247

Wade, S. M. (2004). Parenting influences on intellectual development and educational achievement, in M. Houghughi and N. Long (Eds). Handbook of parenting. Theory and research for practice. London, England: Sage Publications.

Wilson, V. (2000). Education Forum on Teaching Thinking Skills Report. Edinburgh: Scottish Council for Research in Education. Retrieved from: http://docs.sciesocialcareonline.org.uk/fulltext/educthinking.pdf 


\section{Appendix 1}

\section{QUESTIONNAIRE}

\begin{tabular}{|c|c|c|c|c|c|c|}
\hline No. & Statement & \multicolumn{5}{|c|}{ Agree..............Disagree } \\
\hline $\mathbf{A}$ & \multicolumn{6}{|l|}{ Self-Concept } \\
\hline 1 & $\begin{array}{l}\text { If I find it difficult to work on Economics } \\
\text { problems, I will still try to solve them myself. }\end{array}$ & 5 & 4 & 3 & 2 & 1 \\
\hline 2 & $\begin{array}{l}\text { If I get a low marks in Economics, then I will } \\
\text { study hard. }\end{array}$ & 5 & 4 & 3 & 2 & 1 \\
\hline 3 & $\begin{array}{l}\text { Each time the test takes place, I am sure of the } \\
\text { answers I am working on. }\end{array}$ & 5 & 4 & 3 & 2 & 1 \\
\hline 4 & $\begin{array}{l}\text { I will not do Economics work if I do not } \\
\text { understand the material taught by the teacher. }\end{array}$ & 5 & 4 & 3 & 2 & 1 \\
\hline 5 & I can always do Economics problems well. & 5 & 4 & 3 & 2 & 1 \\
\hline 6 & $\begin{array}{l}\text { I will examine myself where my weakness lies } \\
\text { by discussing questions related to Economics. }\end{array}$ & 5 & 4 & 3 & 2 & 1 \\
\hline 7 & $\begin{array}{l}\text { I feel that I can take the Economics test } \\
\text { without help from others }\end{array}$ & 5 & 4 & 3 & 2 & 1 \\
\hline 8 & $\begin{array}{l}\text { I feel that Economics is a subject that I am } \\
\text { good at. }\end{array}$ & 5 & 4 & 3 & 2 & 1 \\
\hline 9 & $\begin{array}{l}\text { I feel the dumbest in class so I feel unable to } \\
\text { study Economics. }\end{array}$ & 5 & 4 & 3 & 2 & 1 \\
\hline 10 & $\begin{array}{l}\text { I have difficulty doing Economics tests, which } \\
\text { require the ability to understand the questions } \\
\text { given. }\end{array}$ & 5 & 4 & 3 & 2 & 1 \\
\hline B & \multicolumn{6}{|l|}{ Family Environment } \\
\hline 11 & $\begin{array}{l}\text { My parents want their children to be highly } \\
\text { educated. }\end{array}$ & 5 & 4 & 3 & 2 & 1 \\
\hline 12 & $\begin{array}{l}\text { of my parents stressed the importance of } \\
\text { education. }\end{array}$ & 5 & 4 & 3 & 2 & 1 \\
\hline 13 & $\begin{array}{l}\text { My parents bought textbooks and other } \\
\text { learning needs. }\end{array}$ & 5 & 4 & 3 & 2 & 1 \\
\hline 14 & $\begin{array}{l}\text { My parents always prioritize spending on my } \\
\text { education. }\end{array}$ & 5 & 4 & 3 & 2 & 1 \\
\hline 15 & $\begin{array}{l}\text { Parents give rules for study time and playtime } \\
\text { at home. }\end{array}$ & 5 & 4 & 3 & 2 & 1 \\
\hline 16 & $\begin{array}{l}\text { My parents provide my learning facilities to } \\
\text { support me in improving thinking skills, such } \\
\text { as laptops/computers, calculators, books, } \\
\text { writing alt, etc. }\end{array}$ & 5 & 4 & 3 & 2 & 1 \\
\hline 17 & $\begin{array}{l}\text { Parents always give encouragement and } \\
\text { enthusiasm for learning. }\end{array}$ & 5 & 4 & 3 & 2 & 1 \\
\hline 18 & $\begin{array}{l}\text { Homework provided by the teacher is always } \\
\text { checked first by parents at home }\end{array}$ & 5 & 4 & 3 & 2 & 1 \\
\hline
\end{tabular}




\begin{tabular}{|c|c|c|c|c|c|c|}
\hline 19 & $\begin{array}{l}\text { My parents never asked me about my } \\
\text { difficulties while studying and doing } \\
\text { homework. }\end{array}$ & 5 & 4 & 3 & 2 & 1 \\
\hline 20 & $\begin{array}{l}\text { Parents give me free time to consult about } \\
\text { education. }\end{array}$ & 5 & 4 & 3 & 2 & 1 \\
\hline 21 & $\begin{array}{l}\text { My parents support education according to } \\
\text { my interests and talents. }\end{array}$ & 5 & 4 & 3 & 2 & 1 \\
\hline 22 & I often disagree with my parents. & 5 & 4 & 3 & 2 & 1 \\
\hline 23 & $\begin{array}{l}\text { My parents tend to be careless if I make } \\
\text { mistakes. }\end{array}$ & 5 & 4 & 3 & 2 & 1 \\
\hline 24 & $\begin{array}{l}\text { My parents give me the freedom to do any } \\
\text { activity. }\end{array}$ & 5 & 4 & 3 & 2 & 1 \\
\hline 25 & $\begin{array}{l}\text { My parents always condition me not to play } \\
\text { with friends at certain times. }\end{array}$ & 5 & 4 & 3 & 2 & 1 \\
\hline 26 & $\begin{array}{l}\text { I was taught by parents to be an independent } \\
\text { person. }\end{array}$ & 5 & 4 & 3 & 2 & 1 \\
\hline 27 & $\begin{array}{l}\text { My parents ask about my learning activities at } \\
\text { school. }\end{array}$ & 5 & 4 & 3 & 2 & 1 \\
\hline 28 & $\begin{array}{l}\text { My parents took the time to take me for a } \\
\text { walk or recreation. }\end{array}$ & 5 & 4 & 3 & 2 & 1 \\
\hline $\mathrm{C}$ & \multicolumn{6}{|l|}{ Learning Environment } \\
\hline 29 & $\begin{array}{l}\text { I have difficulty understanding the lesson } \\
\text { with new teacher teaching techniques. }\end{array}$ & 5 & 4 & 3 & 2 & 1 \\
\hline 30 & $\begin{array}{l}\text { I am bored with the method used by the } \\
\text { teacher who teaches. }\end{array}$ & 5 & 4 & 3 & 2 & 1 \\
\hline 31 & $\begin{array}{l}\text { Teachers always give assignments to students } \\
\text { to find solutions to overcome problems } \\
\text { related to the Economics subject. }\end{array}$ & 5 & 4 & 3 & 2 & 1 \\
\hline 32 & $\begin{array}{l}\text { The the teacher always asks students for } \\
\text { opinions or responses on issues related to } \\
\text { Economics materials. }\end{array}$ & 5 & 4 & 3 & 2 & 1 \\
\hline 33 & $\begin{array}{l}\text { Schools provide adequate and complete } \\
\text { facilities and infrastructure to support } \\
\text { teaching and learning activities in schools. }\end{array}$ & 5 & 4 & 3 & 2 & 1 \\
\hline 34 & $\begin{array}{l}\text { The facilities in the class are complete so the } \\
\text { atmosphere is comfortable when teaching and } \\
\text { learning activities. }\end{array}$ & 5 & 4 & 3 & 2 & 1 \\
\hline 35 & $\begin{array}{l}\text { The teacher allows students to choose the type } \\
\text { of test expected. }\end{array}$ & 5 & 4 & 3 & 2 & 1 \\
\hline 36 & $\begin{array}{l}\text { The teacher gives a response or comment on } \\
\text { the results of student work. }\end{array}$ & 5 & 4 & 3 & 2 & 1 \\
\hline 37 & $\begin{array}{l}\text { The teacher adds points to each student who } \\
\text { answers questions during the learning } \\
\text { process. }\end{array}$ & 5 & 4 & 3 & 2 & 1 \\
\hline 38 & $\begin{array}{l}\text { The teacher gives prizes in the form of items } \\
\text { to students who can answer questions. }\end{array}$ & 5 & 4 & 3 & 2 & 1 \\
\hline
\end{tabular}




\section{Appendix 2}

\section{Higher- Order Thinking Skills (HOTS) in Economics learning}

1. A taxpayer has:

- Land area of 2,000 $\mathrm{m}^{2}$ with a selling price of $\mathrm{Rp} 300,000 / \mathrm{m}^{2}$.

- The fence along the 200 height of $2 \mathrm{~m}$ with a selling price of $100,000 / \mathrm{m}^{2}$.

- Building area of $1,500 \mathrm{~m}^{2}$. If the building value is not subject to tax of Rp. $12,000,000.00$, if the PBB-P2 tariff is $0.1 \%$ and the amount of PBB-P2 to be paid is $\operatorname{Rp} 1,378,000.00$, then the selling price of the building is:

a. $\operatorname{Rp} 2.000,00 / \mathrm{m}^{2}$

b. $\operatorname{Rp} 3.000,00 / \mathrm{m}^{2}$

c. $\operatorname{Rp} 5.000,00 / \mathrm{m}^{2}$

d. $\operatorname{Rp} 8.000,00 / \mathrm{m}^{2}$

e. $\operatorname{Rp} 9.000,00 / \mathrm{m}^{2}$

2. Taxable income Rates:

1. $0 \mathrm{~s} / \mathrm{d} \operatorname{Rp} 25,000,000 \quad 5 \%$

2. USD $25,000,000$ up to $50,000,000 \quad 10 \%$

3. Rp $50,000,000$ up to $100,000,000 \quad 15 \%$

4. $\operatorname{Rp} 100,000,000$ up to $200,000,000 \quad 25 \%$

5. $\operatorname{Rp} 200,000,000$ up to $\quad 35 \%$

No Income Taxable:

Taxpayer Rp. 13,200,000. -

The wife does not work Rp. 1,200,000. -

Child (Maximum 3 children) @ Rp. 1,200,000. -

Mr. Ahmad, a private bank employee, has income after deducting the position fund and insurance contribution in the amount of Rp. 56,000,000.- a year. He has a wife who does not work with 2 children. Based on the data above, the amount of Income tax owed by Mr. Ahmad is:
a. $\operatorname{Rp} 8.400 .000 .-$
b. $\operatorname{Rp} 6.600 .000$.-
c. $\operatorname{Rp} 5.600 .000 .-$
d. $\operatorname{Rp} 4.400 .000$.-
e. $\operatorname{Rp} 2.670 .000$.-

3. Mr. Bagaskoro is an Indonesian citizen who has income from Indonesia, every year actively paying taxes to the government. Mr. Bagaskoro in paying taxes and reporting income taxes entrusted to third parties is a tax collection system ...

a. Official assessment system

b. Withholding system

c. Multimatic system

d. Economics official system

e. Rental official system 
4. Ms. Yane is an entrepreneur engaged in catering business having wealth in the form of:

- the land area of $400 \mathrm{~m}^{2}$ with a selling price of $\mathrm{Rp} 400,000.00 / \mathrm{m}^{2}$

- of $250 \mathrm{~m}^{2}$ house with a selling value of $\mathrm{Rp} 650,000.00 / \mathrm{m}^{2}$

- $150 \mathrm{~m}^{2}$ luxury park with a selling value of IDR $150,000.00 / \mathrm{m}^{2}$

- Luxury fence length $50 \mathrm{~m}$, height $1.60 \mathrm{~m}$ with a selling price of IDR $200,000.00 / \mathrm{m}^{2}$

Provisions: the sale value of taxable objects IDR 8,000. 000,00. The amount of land and building tax owed by Mrs. Yane is:
a. Rp. $314,000.00$
b. Rp. $322,000.00$
c. Rp. $349,000.00$
d. Rp. $353,000.00$
e. Rp. $361,000.00$

5. Mrs. Vero is an entrepreneur engaged in the catering business. He has a land area of $300 \mathrm{~m}^{2}$ with a selling value of $\operatorname{Rp} 500,000 / \mathrm{m}^{2}$. Building an area of $200 \mathrm{~m}^{2}$ with a selling value of $R p 700,000 / \mathrm{m}^{2} .100 \mathrm{~m}^{2}$ luxury garden with a selling value of IDR 200,000 / $\mathrm{m}^{2}$ and a luxurious fence of 100 meters in length with a height of $1.5 \mathrm{~m}$ with a selling value of IDR 200,000 / $\mathrm{m}^{2}$. Selling Value of Non-Taxable Tax Objects Rp 10,000,000.00. Then the building tax payable by Mrs. Vero if the property tax $-\mathrm{P} 2$ tariff is $0.1 \%$ :
a. Rp. $320,000.00$
b. Rp. $325,000.00$
c. Rp. $330,000.00$
d. Rp. $335,000.00$
e. Rp. $340,000.00$

6. Hypothetical data:

\begin{tabular}{|l|l|l|}
\hline Country & Cloth / month & TV/month \\
\hline Indonesia & 80 meters & 20 units \\
\hline Korea & 40 meters & 40 units \\
\hline
\end{tabular}

Based on the table above, the conclusion about the correct exchange rate of goods is:

a. Korea has a specialty of cloth and has an absolute advantage of 3 meters of fabric

b. Korea has a specialty of fabric and has a comparative advantage of 3 meters of fabric

c. Indonesia has a specialty of cloth and has a comparative advantage of $0.75 \mathrm{TV}$ units

d. Indonesia has a TV specialization and has a comparative advantage of 3 meters of fabric

e. Korea has a TV specialty and has an absolute advantage of 3 meters of cloth. 
7. Increasing prices in the market resulting in decreased demand for goods and this has an impact on the company's sales decline, in this case, the marketing manager made several breakthroughs including giving disco $n$, ease of credit terms, payment periods, availability of goods and increasing marketing channels to consumers, the steps taken by marketing managers are the marketing mix strategy steps...

a. price and place

b. product and place

c. targeting and price

d. positioning and promotion

e. positioning and promotion

8. Consider the following statements:

1. In the first quarter of 2018, Indonesia has the value of exports of goods and services amounted to $\$ 2.8$ million while the value of imports amounted to US $\$ 1,800,000$ US

2. In Quarter II in 2018 Indonesia had a value of US $\$ 3,200,000$ in exports of goods and services while the import value of US $\$ 4,650,000$

3. In the third quarter of 2018 , foreign capital flows into Indonesia both for shortand long-term investments amounted to $\$ 70,000,000$ US while to repay debt and interest on foreign loans amounting to the US $\$ 56,450,000$

4. At the end of January 2019, the flow of non-binding foreign aid for victims of the earthquake and tsunami in NAD and North Sumatra amounted to the US $\$ 24,000,000$

5. In the fourth quarter of 2018 , the service balance in Internacional payments experienced a US $\$ 1,200,000$ fee. based on the data above which could cause the value of US $\$$ to rise or the value of the rupiah down is:

a. 1 and 3

b. 3 and 4

c. 4 and 5

d. 2 and 5

e. 3 and 5

9. Hilary, An American tourist visiting Indonesia with the US \$ 8,350. For purposes while in Indonesia, he exchanged his money with the rupiah. The prevailing exchange rate at the time was; Purchase exchange rate of Rp13,300.00 per 1 US \$; Selling rate of Rp13,450.00 per 1 US \$. While in Indonesia he spent as much as Rp62,820,000.00 When he returned to his country Hilary returned to exchanging his rupiah for US dollars. The prevailing exchange rate at that time is: Purchase exchange rate $\operatorname{Rp~} 13,350.00$ per 1 US \$ rate Rp 13,500.00 per 1 US \$ Selling exchange. Then the total dollar received by Hilary was:
a. US $\$ 3,356.96$
b. US $\$ 3,465.96$
c. US $\$ 3,572.96$
d. US $\$ 3,672.96$
e. US $\$ 3,772,96$ 
10. The following table shows the selling rate and buying rate of the currencies of three countries.

\begin{tabular}{|l|l|l|}
\hline Currency & Buying rate & Selling rate \\
\hline USD & USD 13100.00 & USD13200.00 \\
\hline SGD & USD 9702.00 & USD 9803.00 \\
\hline AUD & USD. 9,955.00 & Rp 10,061.00 \\
\hline
\end{tabular}

Mr. Ahmad plans to visit three countries, namely Singapore, Australia, and America, he needs as much as USD 2,500, SGD 3,000, and AUD 4,500. The amount of rupiah he needed to get the three currencies were:
a. Rp. $106,653,500.00$
b. Rp. $106,853,500.00$
c. Rp. $107,683,500.00$
d. Rp. $108,853,500.00$
e. Rp. $109,653,500.00$

11. Balance of Payment (US) \$ billion.

\begin{tabular}{|c|l|l|l|l|}
\hline \multirow{2}{*}{ Description } & \multicolumn{2}{|c|}{2017} & \multicolumn{2}{c|}{2018} \\
\cline { 2 - 5 } & \multicolumn{1}{|c|}{ Imports } & \multicolumn{1}{|c|}{ Exports } & \multicolumn{1}{|c|}{ Imports } & Exports \\
\hline Trade Balance & & & & \\
Oil and Gas Oil & $38,327.0$ & $17,891.0$ & $40,365,0$ & $17,889.0$ \\
Not oil and gas & $139,068.0$ & $152,925.0$ & $134,109.0$ & $149,960.0$ \\
\hline Balance & - & $6,579.0$ & & $6,625.0$ \\
\hline Balance of Services & $33,444,0$ & 23113.0 & 33990.0 & $22,562,0$ \\
\hline Balance & & 10331.0 & & 11428.0 \\
\hline Current Account & $193.929,0$ & & & $210.839,0$ \\
& $208.464,0$ & & & \\
\hline Balance & $190.411,0$ & & & 18053.0 \\
\hline $\begin{array}{c}\text { Balance Capital and } \\
\text { Financial Account }\end{array}$ & 30068.0 & 54964.0 & $39,629.0$ & $62,360.0$ \\
\hline Balance & $24,896.0$ & - & $22,731.0$ & - \\
\hline
\end{tabular}

Based on the table above, the impact that will occur is:

a. balance of payments in 2017 experienced a deficit of US \$ 7,986 and in 2018 a deficit of US $\$ 4,678$ billion so that the country's debt increased

b. balance of payments in 2017 experienced a surplus of US $\$ 7,986$ so that savings increased and in 2018 a deficit of US \$ 4,678 billion so that the state debt becomes increased

c. balance of payments in 2017 experienced a deficit of US \$7,986 so that the state debt increased and in 2018 there was a surplus of US $\$ 4,678$ billion so that the state savings were increased

d. balance of payments in 2017 had a surplus of US $\$ 7,986$ so the state savings increased and in 2018 there was a surplus of US $\$ 4,678$ billion so that state savings increased

e. balance of payments in 2017 experienced a greater deficit than in 2018 so that state savings increased 
12. Veronika departed from Jakarta on December 25, 2019, to take a vacation to the United States for 2 weeks. Three days before leaving, he exchanged his money in the amount of Rp. 24,000,000.00 in US dollars. During his vacation, he spent the US $\$ 1,800$.

December 2014 January 2015

\begin{tabular}{|l|l|l|l|l|l|l|l|l|}
\hline Date & Currency & Selling & Buy & & Date & Currency & Selling & Buy \\
\hline 20 & US $\$$ & $12.956,00$ & $11.956,00$ & & 6 & US $\$$ & $12.721,00$ & $12.595,00$ \\
\hline 22 & US $\$$ & $12.497,00$ & $12.373,00$ & & 7 & US $\$$ & $12.796,00$ & $12.668,00$ \\
\hline 23 & US $\$$ & $12.518,00$ & $12.394,00$ & & 8 & US $\$$ & $12.795,00$ & $12.667,00$ \\
\hline 24 & US $\$$ & $12.529,00$ & $12.405,00$ & & 9 & US $\$$ & $12.703,00$ & $12.577,00$ \\
\hline
\end{tabular}

After arriving in Jakarta, he immediately exchanged all of his money back into rupiah. How many rupiahs did Veronika receive?
a. $\quad \operatorname{Rp} 1,525,366.82$
b. $\operatorname{Rp} 1,525,466.82$
c. $\operatorname{Rp} 1,525,566.82$
d. $\quad \operatorname{Rp} 1,525,666.82$
e. $\operatorname{Rp} 1,525,866.82$

13. Read the article below and then answer the questions.

\section{An increase in the current account deficit will affect the rupiah}

The current account deficit increase in the current account deficit (CAD) in the second quarter of 2018 of 8 billion US dollars or 3.0 percent of GDP is higher than the previous quarter of 5.7 billion US dollars or 2, 2 percent of GDP.

Widening the current account deficit will affect the rupiah exchange rate to weaken against foreign currencies. The next impact is a decrease in investor confidence that will erode direct investment growth in 2018. (Economist Indef: Bima Yudhistira).

To overcome this, import controls must be carried out, in addition to increasing export performance through trade missions and various fiscal stimulation and increasing tourism foreign exchange (Seconds Finance, August 2018).

Based on the article above, why would a balance of payments deficit cause the rupiah exchange rate to weaken against foreign currencies?

a. the occurrence of a balance of payments deficit causes demand for foreign money to decline, this will cause the value of the rupiah to decline.

b. the occurrence of a balance of payments deficit causes demand for foreign money to increase, this will cause the value of the rupiah to decline.

c. the occurrence of a balance of payments deficit causes demand for foreign money to increase, this will cause the value of the rupiah to rise.

d. the balance of payments deficit causes the demand for the rupiah to increase so that inflation can cause a

e. deficit in the balance of payments causes the demand for foreign currency to decline so that the results of Indonesian exports increase. 
14. Based on the article above, with the policies that have been carried out by the government it turns out that the budget deficit has not been resolved, what impact will this have on the country's economic condition?

a. then it will automatically reduce foreign exchange reserves so that it affects the condition of the national economy because it inhibits economic growth.

b. then it will automatically reduce foreign exchange reserves so that it affects the condition of the national economy because it increases economic growth.

c. then it will automatically increase foreign exchange reserves so that it affects the condition of the national economy because it inhibits economic growth.

d. then it will automatically increase foreign exchange reserves so that it affects the condition of the national economy because it increases economic growth.

e. then it will automatically reduce foreign exchange reserves so that it affects the condition of the national economy because it increases state debt.

15. In the last two years in the trade balance of the State " $X$ ", the total exports were smaller than the total imports, in this case, the trade balance experienced a deficit, to overcome this the government adopted a devaluation policy which resulted in the exchange rate of the domestic currency has decreased against foreign currencies, with the expectation of this policy will increase the value of exports and decrease the value of imports which will improve the economy. In your opinion, the impact of the devaluation policy undertaken by the government on the trade balance that will improve the economy:

a. With an increase in exports and a decline in imports, resulting in a reduction in the supply of domestic goods, which will lead to scarcity.

b. With this policy, imports can be reduced, the goods that we export abroad become depreciated if the importer's currency is not the domestic currency.

c. With this policy, the prices of imported goods become very high when valued in the domestic currency and the goods that we export abroad are declining in value if the importer currency is not the domestic currency

d. With this policy there will be an increase in exports and a decline in imports, it is hoped that domestic companies can develop, as a result, will be able to absorb energy unemployed work.

e. With the devaluation policy, there will be a decrease in the domestic currency so that the prices of exported goods will be very high, while the prices of imported goods will fall. 